\title{
Impact of Capital Structure on Firms Financial Performance and Shareholders Wealth: Textile Sector of Pakistan
}

\author{
Mubeen Mujahid (Corresponding Author) \\ MS \& Research Scholar, Dept. of Management Sciences, Islamia University Bahawalpur \\ E-mail: malikmubeen.awan@yahoo.com \\ Kalsoom Akhtar \\ Visiting Lecturer \& Research Scholar, Dept. of Management Sciences, Islamia University \\ Bahawalpur \\ E-mail: kalsoom_2010@yahoo.com
}

Doi:10.5296/ijld.v4i2.5511

URL: http://dx.doi.org/10.5296/ijld.v4i2.5511

\begin{abstract}
The basic purpose of our research paper is to evaluate the impact of Capital Structure on the Firms Financial Performance and Shareholders Wealth in textile sector of Pakistan. We have conducted the regression analysis on our sample data of 155 textile firms for the year 2006 to 2011. We use the overall textile sector ROA ROE and EPS ratios as accounting measures to evaluate the impact of Capital Structure on Firms Financial Performance and Shareholders wealth. Our results shows that the capital structure positively impact the Firms Financial Performance and Shareholders Wealth.
\end{abstract}

Keywords: Firms Financial Performance, Shareholders wealth, Optimal Capital Structure, Return on Equity, Return on Asset, EPS, Debt to Equity ratio.

\section{Introduction}

In this paper we tried to evaluate the impact of Capital structure on Firm's Financial Performance and Shareholder's wealth. In this paper we use two dependent variables (Firms performance, Shareholder's value) to investigate the one independent variable (Capital structure). We tried to analyse the determinants of capital structure and find out the optimal capital structure that increase the value of the firm's financial performance and shareholder's wealth.

First we have to analyse that what it means by Capital Structure. Capital structure of a firm is referred to the Firm's financing through different sources like Equity (Common and Preferred Equity) and Debt (Short-term and Long-term). Firm's calibrate its debt option for financing its operations by issuing bonds to the general public having the specific prescribed interest rate or taking loan from the banks in the form of notes payable which classified as long-term debt, another option to finance firm's operations is from equity source by issuing common stocks and preferred stocks to the general public. Capital structure of a firm also includes short-term debt in shape of working capital requirements of the firm.

Capital structure refers to as the organizations mix of debt and equity financing as they finance their funds for investment from two sources either to take loan from the bank called debt or issue their shares to general public called the equity financing. According to Saleem (2013) Capital structure of a firm is defined as the various financing alternatives of its assets used by the firm. The combination of debt and equity to finance firm's long-term assets is stated as 
capital structure of the firm. Debt and Equity are the basic components of the firm's capital structure.

According to Lim (2012) The way firm generate the money to finance its operations and in what way it assigns these financing options that he choose to its balance sheet is referred to Firm's capital structure. It represents the total capital of a firm in terms of debt and equity combination to finance firm's operations.

According to San \& Hang (2011) in order to finance firm's overall operations and growth by financing its assets from various sources is dependent upon capital structure of the firm. According to Umar (2012) Debt and Equity is the main financing options used by all the firms. For the purpose of operating a firm, intensity of debt or equity option used by the firm to finance its operations represents the firm's capital structure.

If the organizations are financing through debt they have to pay the interest to the banks and if they are financing through equity they have to give the dividends to the shareholders from their profit and sometimes generate the retained earnings account that they did not distributed to the shareholders but reflecting their profit.

We use the secondary data in our research in the shape of Firms Financial Performance measures in accounting terms like ROA and ROE ratios and Shareholders wealth accounting measure like EPSof the firms.

\subsection{Problem Statement}

* It is quite problematic to design specific general Optimal Capital Structure for the firms that maximize the firm's performance, profitability and Shareholders wealth regardless of their size and other factors.

* The decision about the capital structure having the danger of violating Agency cost theory in our Capital Structure Decisions we have to select the best possible Capital Structure.

* The optimal Capital Structure in different countries and in different economies has different ratios that contribute in the problem of analyzing their impact on firm's performance, Profitability and Shareholders wealth.

\section{Literature Review}

The different organizations having the different capital structure that they feel suitable for them having the different debt to equity mix ratios. The basic goal of every organization is to set optimal capital structure that increase the firms value in terms of performance and increasing the share price and having the minimum cost of capital that we have to pay to our borrowers from which we gave our debt and return that should gave to our equity holders.

The basic definition of optimal capital structure is setting the most suitable mix of equity and debt financing for the firms that can contribute in the overall performance of the firm and its profitability by decreasing the cost of capital normally referred to as Weighted Average Cost of Capital (WACC).

Gupta (n.d.) the firm's capital structure which increases the shareholder's wealth and decreases the firm's cost of capital is referred to optimal capital structure of the firm. The basic goal of optimal capital structure is to decrease the firms cost of capital and increase the shareholders wealth and firms overall performance.

Saleem (2013) expressed that the best possible choice of debt and equity share that will increase the shareholder's wealth is referred to as capital structure of the firm. In above given statement the purpose of setting the capital structure is defined as the set of equity and debt combination that will maximize the shareholders wealth. If you are given the preferences to the shareholders of the firm by giving them the higher returns you are more focused on the shareholders wealth maximization that also results in increasing the overall firm's value in the market due to the goodwill created in the minds of their investors that are shareholders. 
By using some of the literature written by different researchers to evaluate the effect of capital structure of the firm on Firm's Financial Performance and Shareholder's wealth we will try to inference the results either capital structure of a firm positively or negatively affect the firm's financial performance and shareholder's wealth.

Saleem (2013) revealed that the some expert of corporate finance believed that capital structure of a firm can maximize firm's overall value with the help of minimizing its cost of capital which is very debatable issue discussed in corporate finance theory about capital structure to evaluate its impact on overall firm's market value. In above given statement we can inference the result as some of the corporate finance analysts think that for the purpose of increasing firms value in the market the firms have to minimize their cost of capital and given the less returns to the borrowers from which they finance their debt.

San \& Heng (2011) revealed that decrease in WACC results in increasing the value of the firm that is defined as optimal capital structure. There is no any specific formula or theory still designed to conclusively define the optimal structure of the firm that increase the firm's overall value after lots of researches that have conducted on the concept of optimal capital structure. The process of minimizing the weighted-average cost of capital (WACC) that will maximize the firm's value is known as optimal Capital structure selection. There have been unlimited researches done in regard of designing the theory that equally provides the Optimal Capital Structure of all the firms but did not succeeded yet.

Saleem (2013) revealed that by maintaining the balance between benefits of debt and cost of debt associated with that benefit that will results in optimal capital structure according to trade off theory. For the purpose of reducing agency cost and gain tax shield firms chose to finance its operations through debt financing. The benefit from debt financing is that the firms can gain tax benefit and reducing the agency cost by not giving the ownership right to the equity holders if they go for the equity financing rather than debt financing.

In order to analyze the effect of Capital structure on firm's financial performance we have to examine the return on assets of that particular firm. The firms purpose is to select the type of capital structure that increase their returns on assets and in a result increase the profitability of the firm.

Li \& Cui (2003) implies that to increase the worth of equity for shareholders managers make decisions of financing their operations according to capital structure theories. The basic goal of the managers is to maximize the value of the firm by attaining higher profits those results in the maximization of shareholders wealth so we can say that capital structure substantially affect the shareholder's wealth.

San \& Heng (2011) revealed that there is some kind of relationship between firm's financial performance and capital structure of the firm either positive or negative.

Velnampy \& Niresh (2012) revealed that profitability of the firm's is dependent upon the capital structure decisions of the firm having the different debt and equity combination that can well suited to increase the profitability of the firm. The important part of the firm's financial strategy is to prosperous choice and use of its capital. The relationship between firm's capital structure and the firm's profitability is very significant as the profitability of the firm can be directly affected by the capital structure decisions of the firms. Decision about firms Capital structure is very important element in the firms overall strategy.

According to Skopljak \& Luo (2012) Agency cost theory defines that difference of the goals of Managers and the owners of the firms can affect the overall performance of the firm in terms of its market value and profitability.

Chowdhury \& Chowdhury (2010) expressed that in order to increase the shareholder's wealth the suitable selection of capital structure of the firm between debt and equity combination plays the vital role. In order to define firm's value by implementing the process of future cash flows 
discounting technique, WACC is used. The purpose of selecting the right capital structure of the firms is to maximize the firm's value, profitability and shareholders wealth.

Soumadi \& Hayajneh (n.d.) revealed that in the literature written in corporate finance the concept of relationship between firm's performance and capital structure is the most debatable concept that also given the strong considerations by financial economists of both financial and non-financial firms.

By looking at all above discussed researches we can conclude that the relationship between the firm's capital structure and the firms overall performance, profitability and shareholders wealth is present. The firms should look for the optimal capital structure that minimize the WACC and maximize the firm's value and their share price to maximize shareholders wealth.

To measure the financial performance of the firm we can calculate the financial ratio related to the income statement and balance sheet of the firms and try to analyze the impact of capital structure of the firm on these financial ratios that adversely or positively impact the firm's performance.

\section{Methodology}

In order to draw some of the results from our research project first we are developing some hypothesis related to our research and in other step using our selected methodology we will try to accept or reject these hypotheses. Followings are these Hypotheses.

\section{Hypothesis-1}

H1: There is a significant positive relationship between firms Capital structure and Firm's financial performance.

H0: There is a significant negative relationship between firms Capital structure and Firm's financial performance.

\section{Hypothesis-2}

$\mathrm{H} 2$ : There is a significant positive relationship between firms Capital structure and Shareholders wealth.

H0: There is a significant negative relationship between firms Capital structure and Shareholders wealth.

\subsection{Sample}

We have selected the sample of 155 textile firms and evaluate their ROE, ROA, EPS of year 2006 to 2011 to evaluate the impact of Capital Structure on Firm's Financial Performance and Shareholders wealth.

\subsection{Proposed Methodology}

We will try to evaluate the relationship between capital structure and the firm's financial performance, and shareholders wealth. By looking at their Financial Performance ratios like ROE, ROA to check their performance in lights of having the specific distinct capital structure of each firm. For the purpose of checking the relationship between Capital structure and Shareholders wealth we use the Stock Price and EPS of different firms. We apply Regression analysis on the data to inference the research result in quantitative notation.

By using the above discussed methodology we try to reject or accept the hypothesis that we are generated. 


\section{Results}

Coefficients $^{\mathrm{a}}$

\begin{tabular}{|c|c|c|c|c|c|c|}
\hline \multirow{2}{*}{\multicolumn{2}{|c|}{ Model }} & \multicolumn{2}{|c|}{$\begin{array}{l}\text { Unstandardized } \\
\text { Coefficients }\end{array}$} & \multirow{2}{*}{\begin{tabular}{|l}
$\begin{array}{l}\text { Standardized } \\
\text { Coefficients }\end{array}$ \\
Beta
\end{tabular}} & \multirow[b]{2}{*}{$\mathrm{t}$} & \multirow[b]{2}{*}{ Sig. } \\
\hline & & B & Std. Error & & & \\
\hline \multirow[t]{2}{*}{1} & (Constant) & 55.070 & 13.125 & & 4.196 & .014 \\
\hline & $\mathrm{CE}$ & -25.309 & 6.949 & -.877 & -3.642 & .022 \\
\hline
\end{tabular}

a. Dependent Variable: ROE

Significance level is less than $5 \%$ so we cannot reject the Ho hypothesis.

Coefficients $^{\mathrm{a}}$

\begin{tabular}{|c|c|c|c|c|c|c|}
\hline \multirow{2}{*}{\multicolumn{2}{|c|}{ Model }} & \multicolumn{2}{|c|}{$\begin{array}{l}\text { Unstandardized } \\
\text { Coefficients }\end{array}$} & \multirow{2}{*}{\begin{tabular}{|l}
$\begin{array}{l}\text { Standardized } \\
\text { Coefficients }\end{array}$ \\
Beta
\end{tabular}} & \multirow[b]{2}{*}{$\mathrm{t}$} & \multirow[b]{2}{*}{ Sig. } \\
\hline & & B & Std. Error & & & \\
\hline \multirow[t]{2}{*}{1} & (Constant) & 19.280 & 4.602 & & 4.189 & .014 \\
\hline & $\mathrm{CE}$ & -8.838 & 2.437 & -.876 & -3.627 & .022 \\
\hline
\end{tabular}

a. Dependent Variable: ROA

Significance level is less than 5\% so we cannot reject the $\mathrm{H} 1$ hypothesis.

Coefficients $^{\mathrm{a}}$

\begin{tabular}{|c|c|c|c|c|c|c|}
\hline \multirow{2}{*}{\multicolumn{2}{|c|}{ Model }} & \multicolumn{2}{|c|}{$\begin{array}{l}\text { Unstandardized } \\
\text { Coefficients }\end{array}$} & \multirow{2}{*}{\begin{tabular}{|l}
$\begin{array}{l}\text { Standardized } \\
\text { Coefficients }\end{array}$ \\
Beta
\end{tabular}} & \multirow[b]{2}{*}{$\mathrm{t}$} & \multirow[b]{2}{*}{ Sig. } \\
\hline & & B & Std. Error & & & \\
\hline \multirow[t]{2}{*}{1} & (Constant) & 23.034 & 6.946 & & 3.316 & .029 \\
\hline & $\mathrm{CE}$ & -11.401 & 3.678 & -.840 & -3.100 & .036 \\
\hline
\end{tabular}

a. Dependent Variable: EPS

Significance level is less than 5\% so we cannot reject the $\mathrm{H} 2$ hypothesis. 


\section{Findings \& Discussions}

We apply regression analysis on the given data of 2006 to 2011 including ROE, ROA, EPS and Stock price as dependent variable, (Firms Financial Performance and Shareholders wealth) measures and Debt to Equity ratio as Independent variable measure to evaluate the impact of Capital Structure on the Firms Financial Performance and Shareholders wealth. We made our decisions on the significance level if the significance level is less than $5 \%$ we asserts the result in a way that there is a positive relationship between Capital Structure and Firm's Financial Performance and Shareholders wealth.

The significance level of D/E ratio to ROE and D/E ratio to ROA is 0.022 which is less than 5 $\%$ and we can asserts the result that capital structure impact the Return on Equity ratio in a positive way. By looking at the above results the $\mathrm{H} 1$ hypothesis is accepted which tells us that there is a significant positive relationship between Capital Structure and Firm's Financial Performance of the firm.

The significance level of D/E ratio to EPS is 0.036 which is less than $5 \%$ and we can conclude that capital structure impact the EPS in a positive way. By looking at the above results the Second $\mathrm{H} 2$ hypothesis is accepted which tells us that there is a significant positive relationship between Capital Structure and Shareholders wealth of the firm.

\section{Conclusion}

We can conclude our research that the Capital structure of the firms has the significant positive impact on the Firms Financial Performance and Shareholders wealth. We have done the regression analysis on 6 years data from 2006 to 2011 of Overall textile sector including 155 firms to analyze the impact of Capital structure on the Firms Financial Performance and Shareholders wealth in Textile sector of Pakistan. We have used ROE and ROA ratios as Firms performance measures to assess the impact of Capital structure on the Firms financial performance and EPS ratio as shareholders wealth measure to check the affiliation between Capital structure of the firms and their shareholders wealth. Our results show that there is a significant positive relationship between capital structure and firm's financial performance and shareholders wealth in textile sector of Pakistan.

\section{Acknowledgement}

I want to acknowledge my parents for this research who gave me the confidence and courage to start my research work and fully supports me during my research.

\section{References}

Saleem, F . , \& Rafique, B. (2013). The determination of capital structure of oil and gas firms listed on Karachi stock exchange in Pakistan. Interdisciplinary journal of contemporary research in business. 9. 225-235. http://journal-archieves27.webs.com/225-235.pdf

Lim, T .C . , Chai, R ., Zhao, D . , \& Lim, X .Y. (2012). Capital structure and political patronage: Evidence from China. American journal business and management. 1 (4) 177-182. Umar, M ., Tanveer, Z ., Aslam, S . \& \& Sajid, M. (2012). Impact of capital structure on firms financial performance: Evidence from Pakistan. Research journal of finance and accounting. 3 (9). 1-12.p.

https://www.google.com.pk/?gws_rd=cr\&ei=L1pWU-v_Eaez0QWp24GYBg\#q=Capital+Str ucture+and+Corporate+Performance+of+Malaysian+Construction+Sector\%3A+International +Journal+of+Humanities+and+Social+Science. \%2C+1+(2)\%3A+28-36.+

Gupta, P ., Srivastava, A . , \& Sharma, D. (n.d). Capital Structure and Financial Performance: Evidence from India. P.2. http://www.wbiconpro.com/319-Gupta.pdf 
San, O .T . , \& Heng, T .B. (2011). Capital Structure and Corporate Performance of Malaysian Construction Sector. International Journal of Humanities and Social Science. 1 (2). 28-36.

Li, H . \& Cui, L. (2003). Empirical Study of Capital Structure on Agency Costs in Chinese Listed Firms. Nature and Science. 1 (1). 12-20.

Velnampy, T . , \& Niresh, J . A. (2012). The Relationship between Capital Structure \& Profitability. Global Journal of Management and Business Research. 12 (13). 1. http://www.journalofbusiness.org/index.php/GJMBR/article/viewFile/766/695

Skopljak, V . , \& Luo, R .H. (2012). Capital Structure and Firm Performance in the Financial Sector: Evidence from Australi. Asian Journal of Finance \& Accounting. 4 (1). 278-298. http://dx.doi.org/10.5296/ajfa.v4i1.1319

Chowdhury, A . , \& Chowdhury, S .P. (2010). Impact of capital structure on firm's value: Evidence from Bangladesh. Business and Economic Horizons., 3 (3). 111-122. http://dx.doi.org/10.15208/beh.2010.32

Soumadi, M .M . , \& Hayajneh, O .S. (n.d). CAPITAL STRUCTURE AND CORPORATE PERFORMANCE EMPIRICAL STUDY ON THE PUBLIC JORDANIAN SHAREHOLDINGS FIRMS LISTED IN THE AMMAN STOCK MARKET. European Scientific Journal. 8 (22). 173-189.

Arifeen, $S$ et al. (2011). FINANCIAL STATEMENTS ANALYSIS OF COMPANIES (NON-FINANCIAL) LISTED AT KARACHI STOCK EXCHANGE: State Bank of Pakistan. p.36. http://www.sbp.org.pk/departments/stats/bsa.pdf 